\title{
Enterprising education - a research on students as agents of change in social entrepreneurship
}

\author{
Oana Codruta GAUCA \\ The Bucharest University of Economic Studies, Bucharest, Romania \\ gaucaoana@yahoo.com \\ Denisa DRAGAN \\ The Bucharest University of Economic Studies, Bucharest, Romania
}

\begin{abstract}
This article is a study on the awareness and understanding of social entrepreneurship among students. Moreover, the article aims to emphasize the different meanings this buzz word has developed, whether it is the purpose of social entrepreneurship, the fields it activates in or the profit which should or should not be distributed. We aim to cover aspects of the definition of the social entrepreneurship field, as well as the ways in which students act as agents of change. The main research methodologies used except for literature review are interviews and case studies for several social business developed by students. The interviews are with no predetermined questions, in order to allow flexibility. The article wants to demonstrate that students are the emerging social entrepreneurs and important initiators of change in this field. In this regards, students should be educated and should develop skills within the universities programs, skills that are very specific compared to simple entrepreneurship. The main theoretical contribution to the field of education is the proven necessity that education facilities need to educate themselves. In order to create our future entrepreneurs as well as provide them with the skills set necessary to become entrepreneurs, education needs to become enterprising.The main practical contribution is the proof of students being involved in the change of society around them and main contributors to their environment.
\end{abstract}

Keywords: social entrepreneurship, student, education, change, higher education.

\section{Introduction}

Education has been perceived for a long time as a great influence of wellbeing, including on economic growth. As Hanushek and Wo“ßmann (2010) fantastically summarize, "quality of education - measured on an outcome basis of cognitive skills - has powerful economic effects. Economic growth is strongly affected by the skills of workers. What people know matters."(p. 251).

But is there a direct link between the entrepreneurial qualities of education and the extent of entrepreneurial skills that people acquire whilst in university programs in order to enhance social innovation and social entrepreneurship? We argue that there is, a very powerful one.

Social innovation has become a buzz word of this decade, mostly because the amazing technological advancements and the survival of the competitive environment is based almost solely on it. However, the areas of study connected to innovation used to be, until recently, the business environment and to information technologies. Even though not it is not new as idea, but recent as developed concept, social innovation started to address the needs of the society and the problems of the society that are to be solved through innovative ideas, also in the world of business or businessmen that have already approached innovation in other fields rather than social. 
Ideas come from people. People are educated within the school system, which was created for need of different times and are now adapting to the current realities. Therefore, the school system has to become socially innovative as well, in order to created social entrepreneurs and agents of change.

More than half of the findings in the Web of Science search results for "Social Innovation in title" , from 1966 until 2014 were in the field of Business Economics, Public Administration and Computer Science (approx. 401 results out of 835), whereas only 61 results out of 835 result are in the field of Social Issues, Educational Research, Medical Technology and Pharmacy.

However, within the last 3 years, social innovation's field has expanded greatly in the education, world development and social sciences, with more than 3.500 Articles written.

The connection between social innovation, social entrepreneurship and universities, can be described as follows:

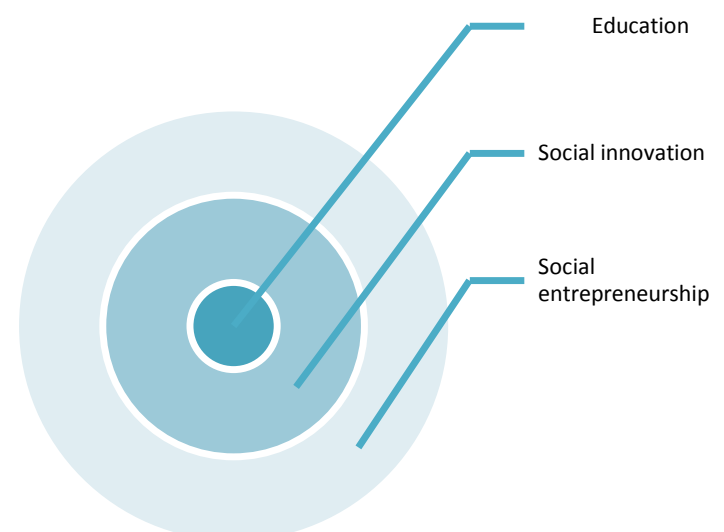

Figure 1. Relationship between education and entrepreneurship

Source: Authors' own research.

The scheme represents an inclusion relationship that starts with education as the center, as education facilities are the nurturing systems of innovation and entrepreneurial activities. As a the base of the pyramid and the center of the scheme, the educational system creates a wave effect by fostering social innovation because it leads to creation social entrepreneurs that can implement the innovative ideas and create value for the society.

The research question thus develops - does the educational system itself need to become enterprising in order to foster social innovation and social entrepreneurship? Moreover, are students agents of change in social innovation? These are the two questions we shall approach in this short study.

\section{Literature review}

\section{Social responsibility}

First of all, social responsibility can be defined as the interest of any individual or organization to assume responsibility of the effects of his/its actions upon the community, other that his/its immediate circle (Individual social responsibility, 2008).

This assumes that individuals are connected to their community and that they are aware of the actions they enterprise which might impact other groups. This attribute of 
observer is most of the times common for all individual. However, the assessment of the impact individual actions can have is not so common and should be one of the attributes to be enhanced in our community.

Second of all, it can be considered as ideological, concerned with moral or ethical aspects, but it can also have a legal nature. It can refer to the government (good governance), enterprises (corporate social responsibility) or the citizen (civic responsibility) (Stojanova, 2009).

Concepts that are closely related to an individual nature are usually hard to be defined, and if they emphasize a positive aspect, are usually considered ideological. However, I believe that social responsibility is not ideological, but is a primary concern of each individual. The status of the community we live in, of the environment we use and of the people we communicate with is what defines our human nature, reason for which ideology has no or should not belong here. Moreover, it is not the responsibility that usually lack, but it is the understanding of the power each individual has to make a change and that individual's ability to gather resources for that change to happen.

Ideas individuals have usually stick more that the individuals themselves, reason for which a powerful idea created through social responsibility, can create more change than the individual alone can quantify.

\section{Social entrepreneurship and social business}

Social entrepreneurship is a "simple term with a complex range of meanings" (Trexler, 2008). The lack of a unified understanding of the concept (Zahra et al., 2009) is one of the major barriers to the advancement of scholarly research on the subject.

Among literature, there have been three characteristics that seem to stand out when talking about social entrepreneurship: the necessity of a social character, the obligation of the innovative character and the role of the economic value.

The general purpose of business or technological innovation is profit, whereas this economic dimension is not the primary reason in the social field. This can be proved by several social innovation actions that took place in the 19th century, together with industrialization, like for example 'mutual self- help, microcredit, building societies, cooperatives, trade unions, reading clubs and philanthropic business leaders creating model towns and model schools. In 19th and early 20th century Britain civil society pioneered the most influential new models of childcare (Barnardos), housing (Peabody), community development (the Edwardian settlements) and social care (Rowntree).'(Murray et al., 2010).

For several researchers "entrepreneurship" means that the exposure to a market logic is expected for one to be considered a social entrepreneur (Peredo and McLean, 2006). Whether or not this translates into an obligation to have 100\% earned income, however, is one of the criteria that currently seems to receive the least consensus. While some scholars and policymakers attach a lot of importance to the requirement of earned income for a person to be a social entrepreneur (Austin et al., 2006; Boschee and McClurg, 2003; Dorado, 2006), others define social entrepreneurship more narrowly, as economically sustainable ventures that generate social value (Dees, 1998a; Emerson and Twersky, 1996; Mair et al., 2006), regardless of where the revenue comes from.

Social businesses are to be economically sustainable, as any other business and their role as structure of dissemination of social innovations, as well as incubators for testing the 
innovative ideas are extremely important. However, though a debated concept, social businesses are not the main criteria, but social entrepreneurship. Why? Because entrepreneurship is the engine of the social innovation and it creates societal value.

Whereas, as mentioned before, social innovation is the process of creating new knowledge and shaping this knowledge on a certain need, entrepreneurship is the system that transforms knowledge into practice. The most common steps of the entrepreneurial process can be defined as follows:

1. Idea generation and research (already covered by innovation)

2. Idea selection (key aspect of entrepreneurship)

3. Business model and plan

4. Financing scheme

5. Idea implementation

6. Market analysis and harvest

Thus, the relationship scheme is that the entrepreneurial process encompasses and relies on innovation, whereas innovation is not necessarily a starting point of entrepreneurship. Why? Because between the two aspects lies the initiator, which is the entrepreneur itself.

Social entrepreneurs can be defined as 'entrepreneurs with a social mission. However, because of this mission, they face some distinctive challenges and any definition ought to reflect this.

Therefore social entrepreneurship is deeply and solely connected with a social goals and has as objective to create societal value instead of economic value. Moreover, during the past decade, the proposition that even businesses have reason to be concerned and could contribute to poverty alleviation/reduction and development has gained both supporters and critics (Blowfield and Frynas, 2005; Jenkins, 2005; Singer, 2006; Davidson, 2009; Jeppesen and Lund-Thomsen, 2010).

Hence, entrepreneurship proves to be a new way for old and new institutions to survive and thrive, this being true even for higher education institutions which are currently confronted with an increasing competition coming from alternative forms of education and a high degree of internationalization (Marginson, 2006).

The reason for which understanding the above terms individually is necessary, is depicted in the following scheme:

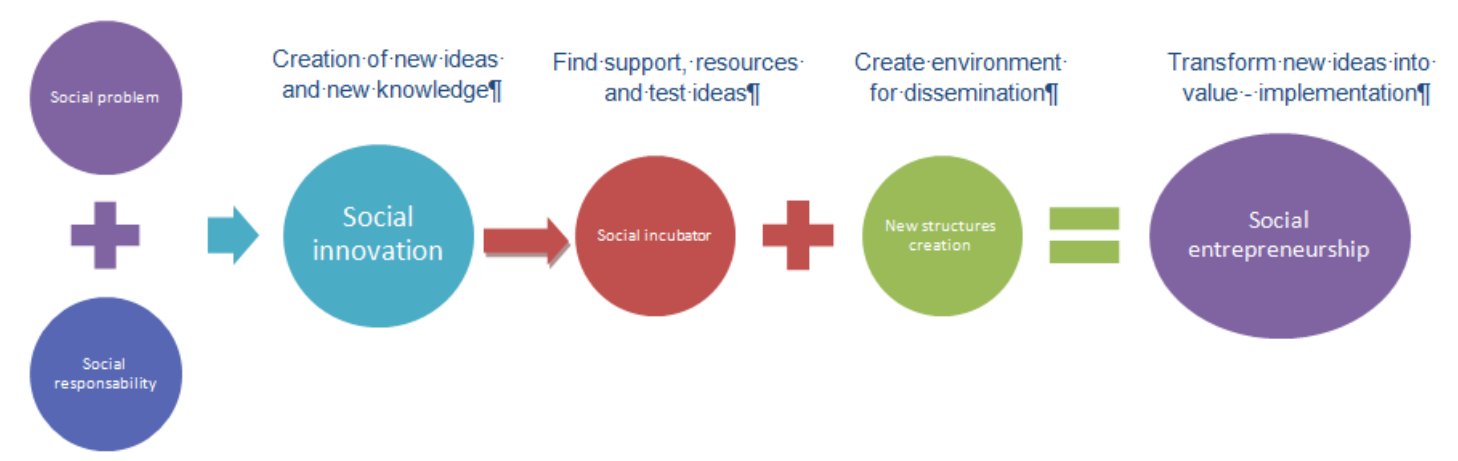

Figure 2. Social innovation scheme of influence

Source: Authors' own research. 
As it can be observed, social innovation is influenced mainly by two aspects: the definition of the social problem that needs to be addressed, as well as the social responsibility that accompanies that problem and urges the innovator to find a solution.

Moreover, in order for the ideas that are gained during the innovative process to become a solution for the problem they address, these ideas have to be tested, resources need to be found for their implementation and dissemination, as well a structure that can allow this.

However, understanding this is only the first step of the process. As observed by Murray et al (2010), the other steps of the innovative process involve developing and prototyping ideas, as well as diffusion and scaling up of the ones that turn out to be viable. As he argued, 'taking a good idea to scale requires skillful strategy and coherent vision, combined with the ability to marshal resources and support and identify the key points of leverage' (p.23).

However, taking a good idea to be tested and scaled cannot be accomplished without social responsibility, which is a necessary motivation of any innovator in the social environment is to be aware and interested in the needs of the society he lives in. Moreover, testing and scaling an idea cannot be developed without the necessary skills of the people who develop it, skills that are to be created and learned in universities, as part of the entrepreneurial process of any type.

Understanding value invites holism rather than particularization, as value creation can simultaneously refer to content and process (Lepak et al. 2007), and thus requires understanding of the evaluation of value as well as the processes involved in creating it, which should be in fact main objectives of the educational facilities.

\section{Students and social entrepreneurship \\ Interview}

Following a small study of 25 students that are following or have followed entrepreneurial studies in Romanian universities, we have found that more than $77 \%$ of these believe that the role of universities is also to develop the entrepreneurial skill set they need to be part of entrepreneurial world (study from 2016). Moreover, the students were selected from different university background, from technical studies, to economical and management studies.

What is however more interesting is that $66.7 \%$ of these students believe that they have developed part of the necessary skills during the courses of their universities, which is an extremely important aspect. This shows that the universities have started to address their needs and create programs that are both sustainable and interesting.

One of the students made the remark "I consider that an idea is not enough. The faculty taught me to test, create a plan and the importance of applying it."

The university environment, though old and with tradition, has to become adaptable to the current environment. Taking into account that the new generation became more and more focused on world problems and ways to address them, from recycling to ocean clean methods, alternative uses of materials, minorities etc., this new generation has to be educated so as to be able to build and solve part of these main problems of interest.

We believe that the most important role that students can play is decisively determined by the way they grow up and learn how to use their potential in order to be 
entrepreneurial and to be an agent of change. However, this also functions the other way around, because even though universities can and should create entrepreneurial skills, students can be also agents of change to make universities more adaptable (Cantaragiu and Hadad).

Thus they can be socially involved also in the change of the universities, programs, teaching methods, methodology and development programs. Students can be one of the most important actors who could make the university environment more enterprising so that they become more entrepreneurial.

In 2013, Forbes mentioned in an online article 4 myths that would prevent students from becoming social entrepreneurs. The first one and the one most valid in Romania is, in our opinion - "No one will take me seriously because I'm just a college student." (http://www.forbes.com/sites/ashoka/2013/02/26/4-myths-that-keep-students-frombecoming-social-entrepreneurs/\#4d7dd4272e34)

Students often think that they don't possess the ability to convince people about an entrepreneurship project or lack the empowerment to do so. This happens because students in our society, specifically the Romanian one, are not treated and seen as agents of change, that can influence and develop society through their ideas.

Hub Romania.

However, things have changed in the past few years in the country, due to Impact

Impact Hub is a worldwide social community center and an innovation lab that incubates social business. It has a presence in more than 80 cities around the world, with 10,000 members and over 2 million beneficiaries. Over 1,000 Start-ups were founded in 2014 and more than 4,000 jobs were created that same year.

In Romania, Impact Hub has members with projects cover all industries and professions, from ecology to urbanism, from social advertising products to fun learning, from innovative online platforms to social integration, from corporate intrapreneurship to consultants and much, much more. We help create scalable business models so that ventures developed at Impact Hub Bucharest become financially sustainable and create real impact. (http://www.impacthub.ro/about-us/)

Impact Hub is also one of the creators and supporters of Social Impact Award, an yearly competition that has been running since 2012. They address to students that wish to change the current social problems in an innovative way, though projects, business and organizations. The ideas can address education, health, the environment, as well as poverty, human rights, discrimination issues etc.

Over the last 5 years, they have gathered together more than 950 students, in Bucharest, Iasi, Cluj-Napoca, Timisoara and Constanta. The results have been astonishing, with more than 132 business ideas, out of which 16 ideas won their confidence and the award of more than 13,000 Euro.

Social Impact Award is also promoted by Global Shapers Bucharest Hub, Social Innovation Solutions and the Alternative University, all as part of the entrepreneurial and social entrepreneurial activity.

Globally, Social Impact Award gathered in 2015 more than 430 teams of students, out which $60 \%$ created implemented their ideas and $35 \%$ created income( http://socialimpactaward.ro/)

The study we previously mentioned, also showed that $80 \%$ of the interviewed students know the meaning of social entrepreneurship and $12 \%$ of them are involved in a 
social entrepreneurship program. This is a very good number for such a small sample, which actually demonstrates the interest of students in this domain.

Out of the interviewed students, many considered that social entrepreneurship creates profit but several comments were done by them, demonstrating the in depth understanding they have regarding this term: Among this we mention "social entrepreneurial business create profit but with social purpose, to be reinvested in society" or "the primary purpose is not profit but creating a change in society".

Regarding the availability of these students to be involved in an entrepreneurial environment, almost $90 \%$ confirmed their interest and more than $50 \%$ addressed directly the desire of becoming a social entrepreneur.

When asked why, $88 \%$ of these believed that social entrepreneurs can change the society to a better version of itself.

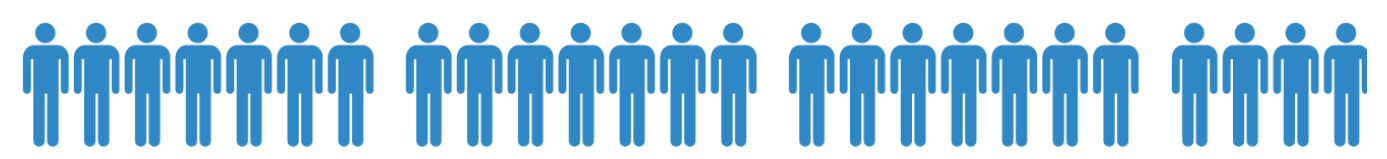

25 sample students - equivalent to one study group
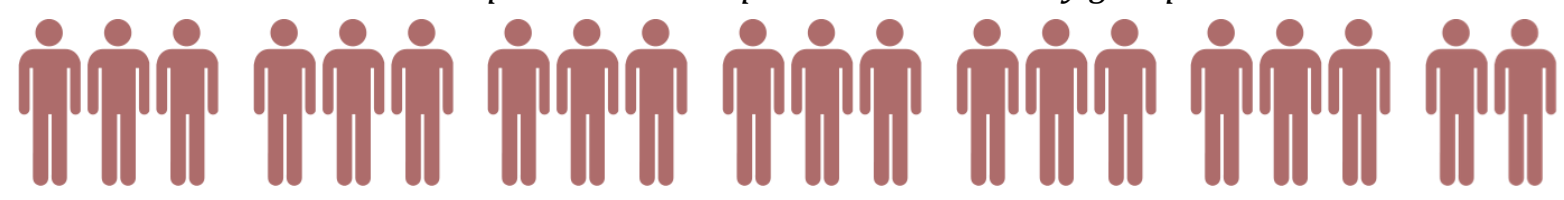

20 students are familiar with social entrepreneurship

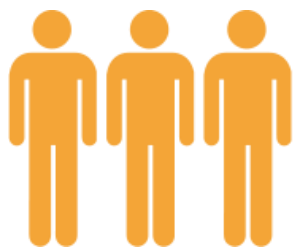

3 STUDENTS ARE SOCIAL ENTREPRENEURS

Figure 3. Students as agents of change - original contribution

Case studies

Source: Authors' own research.

COBI Bicycle

Short description

Cobi bicycle is the first recycling center for bicycles, that has an objective to recondition bicycles and sell them to students from universities at a very low rate, or to people with low income, who cannot afford a new one.

The business was launched in 2014 and is one of the winners of Social Impact Awards that year. COBI helps youngsters to personalize their bike, promote a healthy lifestyle and encourages environment's protection to selective recycling

Besides recondition and recycling, they also offer maintenance services to keep them in good condition. Servicing is provided directly by apprentices. These are mostly young people that are trained for the labor market through the partnership between Cobi Bicycle and an organization caring for abandoned children. Maintenance support is also offered as advice for those who want to do it themselves or subscription for access to equipment.

Agents of change: Costel Eftimie, Elena Croitoru, 24 years' old. 
Results: COBI is recycling used bicycles, being the first recycling center of this kind in Romania, set up to reduce the environment impact of transport.

The team has also developed an apprenticeship program, where they offer training in repairing bicycles and working opportunities to young people coming out of institutions for abandoned children. (Impact Hub, 2016)

\section{INBOX-Student House}

\section{Short description}

This project aims to offer sustainable projects and execution for constructions from martime containers, from campuses, dorm rooms and urban farm concepts. One of the fundeamental values of INBOX is to have a low carbon footprint and be sustainable, with minimum use of resources for construction.

Students need affordable places to live. Currently, in Bucharest, only $30 \%$ are offered dorms for the period of learning, whereas the other $70 \%$ are forced to find private dorms or leasing places, which are expensive and decrease the number of students that follow university studies.

The project was one of the finalists of Social Impact Awards 2016.

Agents of change: Stelian Mustea, 23 years' old

Results: The project is in planning phase; results have to be followed up. Campus Hub is one of the projects under development, a network of dorm rooms accessible for mass market but with good facilities and furnishings.

On September the 1st 2017 it is planned to release a prototype, a 30 rooms unit.

SPICO

Short description

This project wants to create an allergen free kitchen, mainly based on gluten and lactose free recipes. Moreover, it wants to increase the level of information regarding the importance of specialized diets and the benefits/problem of gluten free way of living. Unfortunately, in Bucharest the options are very limited for people who have intolerances, reason for which this concept will be both unique and expected.

The founder also wants to address nutrition courses through workshops and oneon-one meetings with specialized doctors.

The project is currently the winner of the Social Impact Awards 2016.

Agents of change :Roxana Bira, 23years' old

Results: The project is in planning phase; results have to be followed up.

\section{Limits of the research and future plans}

The present research has its limitations, among which the most relevant in our opinion is the small dimensions of the sample groups analyzed both in the interview as well as in the case studies. Moreover, the article misses a valid point of view from the universities side, with regards to the efforts they are making in identifying these need for skills creation and the measures taken to create and adapt in this respect.

Another important limitation of the research is related to the location of the study, which has been Bucharest. Taking into account that the capital city is the most advanced in terms of knowledge, university coverage and channels for social entrepreneurship 
development, we believe that a national study could have different results and might incur a more in depth analysis regarding the needs, dimensions and realities of social innovation in Romania's universities as well as the students implication in the social innovation sector.

Future plans include the nationwide analysis, together with a thorough described process of what universities have to do in order to become enterprising and in order to foster social entrepreneurial skills in students.

\section{Conclusion}

Although social entrepreneurship and social innovation are feisty debated and sometimes misunderstood, we argue the fact that their meaning is simple and starts with the first mission of these types of business which can be rooted to Yunus microcredit - developing a tool for a group of society in need, in order to help that group, develop and evolve.

Having this in mind, any social business has to function on itself, be completely operational and keep the people involved in it at high quality, which means investing in them and paying "in the market salaries".

But what is most important is that social business create profit and that profit is the sole use of its creators, but it is reinvested in other social businesses or purposes. Social businesses are amongst one of the least self-centered activities we can be involved in, as business people.

Social businesses are created through people who understand their value, who are taught to appreciate both their involvements in the society as well as the creation they can contribute to, in improving the world they live in and the education they receive.

Through this article, we argue that students understand this real meaning and are at the age of believing in a change of society and in their power to do it. This new generation of students understands that the educational environment is an important root and basis for their development and they are also very aware of their impact in the society. Thus, they have to be seen as agents of change in this field, who can address needs and find innovative solutions better than any other group or actors involved.

In order for them to assume this role however, they need to possess the skills and believe in their capabilities. And this is the role of the university, which thorough its programs have to become enterprising enough so as to nurture and develop entrepreneurial skills, as well as create development courses and self-knowledge meetings.

Universities need to be more enterprising so that students can become agents of change for the social enterprises' world.

\section{References}

Austin J., Stevenson H., Wei-Skillern J. (2006). Social and commercial entrepreneurship: same, different, or both?, Entrepreneurship Theory \& Practice, 30(1), 1-22

Blowfield, M.E. and J.F. Frynas, (2005). Setting New Agendas: Critical Perspectives on Corporate Social Responsibility in the Developing World, International Affairs, 81(3), 499-513.

Boschee, J., McClurg, J. (2003). Towards a better understanding of social entrepreneurship: Some important distinctions. Retrieved from http://www.caledonia.org.uk/papers/ Social-Entrepreneurship.doc 
Cantaragiu, R. and Hadad, S. (2013). The Importance of Play in Overcoming Fears of Entrepreneurial Failure, Proceedings of the 14th European Conference on Knowledge Management, Kaunas, Lithuania.

Davidson, K. (2009). Ethical concerns at the bottom of the pyramid: where CSR meets BOP. Journal of International Business Ethics. 2(1), 22.

Dees, J.G. (1998). Enterprising nonprofits. Harvard Business Review, 76, 54-69.

PICBE | 797

Dorado, S. (2006). Social entrepreneurial ventures: different values so different processes of creation, Journal of Developmental Entrepreneurship, 11(4), 319-343.

Emerson, J. (1999). Leadership of the whole: the emerging power of social entrepreneurship. Leader to Leader, 13, 12-14.

Hanushek E.A., Wobmann L. (2010). Education and Economic Growth. Retrieved from http://hanushek.stanford.edu/sites/default/files/publications/Hanushek\%2BWoes smann\%202010\%20IntEncEduc\%202.pdf \.

Individual Social Responsability. (2008). Understanding ISR-Individual Social Responsibility. Retrieved from http://www.isrworld.org/2008_06_01_archive.html .

Jenkins, R. (2005). Globalization, Corporate Social Responsibility and poverty, International Affairs, 81(3), 525-540.

Jeppesen, S. (2009). Taking Stock of CSR and SMEs in Development . Working Paper, no. 9. The International Research Network on Business, Development and Society, Copenhagen Business School: Copenhagen.

Lepak D.P., Smith KG and Taylor MS (2007). Value Creation and Value Capture: A Multilevel Perspective, Academy Of Management Review, 32(1), 180-194.

Mair, J., Robinson, J., and Hockerts, K. (2006). Social entrepreneurship. Hampshire and New York: Palgrave Macmillan.

Marginson, S. (2006). Dynamics of national and global competition in higher education, Higher Education, 52(1), 1-39.

Murray R., Caulier Grice, J and Mulgan G. (2010). The open book of social innovation, Retrieved from http://www.nesta.org.uk/library/documents/Social_Innovator_020 310.pdf.

Peredo, A.M and McLean, M. (2006). Social entrepreneurship: a critical review of the concept, Journal of World Business, 41(1), 56-65.

Singer, A.E. (2006). Business strategy and poverty alleviation, Journal of Business Ethics, $66(2), 225-231$.

Stojanova D. (2009). Social Responsibility of citizens. Retrieved from https://www.academia.edu/3750318/Social_Responsibility_of_Citizens_-_2009

Trexler, J. (2008). Social entrepreneurship as an algorithm: Is social enterprise sustainable?, Emergence: complexity and Organization, 3(10), 65-85.

Zahra, S.A., Rawhouser, H.N., Bhawe, N., Neubaum, D.O., and Hayton J.C.. (2008). Globalization of social entrepreneurship opportunities, Strategic Entrepreneurship Journal, 2(2), 117-131. 